- Pedro Puech-Leão

- Lazlo Josef Molnar

- Ilka Regina de Oliveira

- Giovanni Guido Cerri

\section{Prevalence of abdominal}

\section{aortic aneurysms - a screening program in São Paulo, Brazil}

\author{
Hospital das Clínicas, Universidade de São Paulo, São Paulo, Brazil
}

\section{ABSTRRAC I}

CONTEXT: Abdominal aortic aneurysm is an asymptomatic but potentially fatal condition. Elective surgery can prevent death from rupture, and is indicated for aneurysms larger than $45 \mathrm{~mm}$. Because aneurysms tend to grow with time detection of small ones $(>29 \mathrm{~mm}$ ) may lead to a closer follow-up of patients at risk.

OBJECTIVE: To determine the prevalence of abdominal aortic aneurysms in São Paulo, Brazil.

DESIGN: Prospective, descriptive.

SETTING: University Hospital.

PARTICIPANTS: Persons aged 50 years or more were offered, through the press, the opportunity to be screened for abdominal aortic aneurysm. The total number screened was 2,756

PROCEDURE: All were submitted to abdominal palpation and ultrasound examination.

PARAMETER STUDIED: A maximum diameter of $30 \mathrm{~mm}$ or more was considered to be an aneurysm.

RESULTS: Sixty-four aneurysms were detected, nine of which measuring more than $49 \mathrm{~mm}$. Palpation detected 60 aneurysms, but only 20 of these were confirmed by the ultrasound. Conversely, 41 of the ultrasound-detected aneurysms were not palpable. The percentages of abdominal aortic aneurysms found in the subgroups via licasound examination With 95\% confir ultrasound examintion (with $95 \%$ confidence interval) were as follows: total group, 2.3 (1.8 3); men, 4.6 (3.5-5.9); women, 0.6 (0.3-1.1); men aged 60 or more, 6 (4.3-8); women aged 60 or more, $0.9(0.4-1.8)$

CONCLUSION: In São Paulo, Brazil, 1.8 to $3 \%$ of persons aged 50 years or more are expected to have abdominal aortic aneurysms. In the subgroup of men aged 60 or more, the expected prevalence is between 4.3 and $8 \%$.

KEY WORDS: Aortic aneurysm. Aneurysm. Screening. Prevalence. Determination.

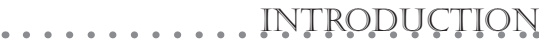

Abdominal aortic aneurysm is an asymptomatic but potentially fatal condition. Diagnosis is usually made during image testing for other diseases. Because death can be prevented by elective surgical intervention, screening is of utmost importance, just as it is for prostate or breast cancer.

For the establishment of public health policies, it is important to know the prevalence of aortic aneurysms in a given population, and especially in subgroups of the population, in order to focus attention on that particular group. Given the fact that this disease has familial incidence, its prevalence may vary between countries and from one ethnic group to another.

The aim of this study was to determine the prevalence of abdominal aortic aneurysms in a non-hospital population in São Paulo, Brazil.

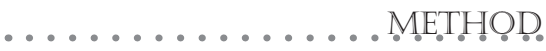

During the month of September 1999, an announcement that Hospital das Clínicas was offering free ultrasound scans for abdominal aortic aneurysms was broadcast on radio and TV stations in São Paulo. Anybody aged 50 years or more was invited to call a special telephone number and make an appointment. Brief appearances by members of the Vascular Surgery Division were sometimes included in the broadcasts, explaining what the disease is about, and the need for screening. Additionally, outdoor banners were placed in the neighborhood of the hospital, and an announcement was added to every water bill in the city. No announcement was made to the public inside the hospital, because the aim was to screen the healthy population and not those being treated for any other disease.

The first 3,000 persons to call were placed on the schedule. Upon arrival at the hospital, the subject was asked if he (or she) had been ever examined for aortic disease, and received the information in writing that he (or she) would be submitted to ultrasonography of the abdominal aorta. The text emphasized the fact that no other abdominal organs would be studied, and also that thoracic aortic aneurysms would not be detected.

Palpation of the abdomen was performed by vascular surgeons, with the patient in the supine position. The aortic pulse was sought and the size of the aorta was described as normal or dilated. Ultrasonography of the abdominal aorta was conducted by radiologists, in two rooms equipped with ultrasound systems (Logic 400, General Electric 3.5 MHz curved array probes). The probe was positioned over the projection of the aorta, and its full extent from the infrarenal segment to the bifurcation was examined. No other organs or structures were examined. The maximum infrarenal diameter was measured in all cases, except for those whose aortic imaging was not clear enough. With the help of dedicated nursing staff, the average number of examinations per hour was 32 .

For the purposes of this study, an aneurysm was defined as a dilatation of more than $29 \mathrm{~mm}$ in diameter. Aneurysms with diameters between 30 and $49 \mathrm{~mm}$ were classified as small, and those exceeding $49 \mathrm{~mm}$ as large. Patients found to have small aneurysms were advised to have the test repeated in six months, and those with aortic diameters of more than $49 \mathrm{~mm}$ were registered for pre-operative evaluation and surgical correction. 


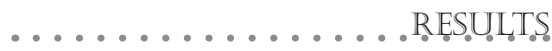

Palpation and ultrasound were performed on 2,799 subjects. Some of those scheduled did not show up, and some came without scheduling and were examined as well. Thirty persons aged less than 50 years came, despite the specificity of the announcements: they were examined as a courtesy, but not included in the final count (and none of these persons had aneurysms). One patient declared that he had a small aneurysm that was under surveillance by his physician and was taking the opportunity for a free check on its diameter: he was also not included in the count, although examined. In twelve cases the aortic image was not adequate for measurement, due to either obesity or excess of air in the intestines. Hence, 2,756 cases were considered as the population sample for statistics.

Sixty-four aneurysms were found in this survey. The distribution according to age and gender is shown in Tables 1 and 2 . In the fe-

\section{Table 3. Results of palpation and}

corresponding confirmation of aneurysms of abdominal aorta by ultrasound examination in a screening study carried out in São Paulo $(\mathbf{n}=2,756)$

\begin{tabular}{lcc} 
Palpation & $\begin{array}{c}\text { Number of } \\
\text { patients }\end{array}$ & $\begin{array}{c}\text { Aneurysm } \\
\text { confirmed } \\
\text { by ultrasound }\end{array}$ \\
\hline Impossible & 298 & 3 \\
\hline Negative & 2,398 & 41 \\
\hline Positive & 60 & 20 \\
\hline
\end{tabular}

male group, nine aneurysms were found, seven in women aged more than 60 years. The only two large aneurysms found in women were also in this age group.

Palpation detected 60 aneurysms, but only 20 of these were confirmed by the ultrasound. Conversely, 41 of the ultrasound-detected aneurysms were not palpable (Table 3). Ultrasound examination was shown to be more accurate than palpation in the detection of the disease.

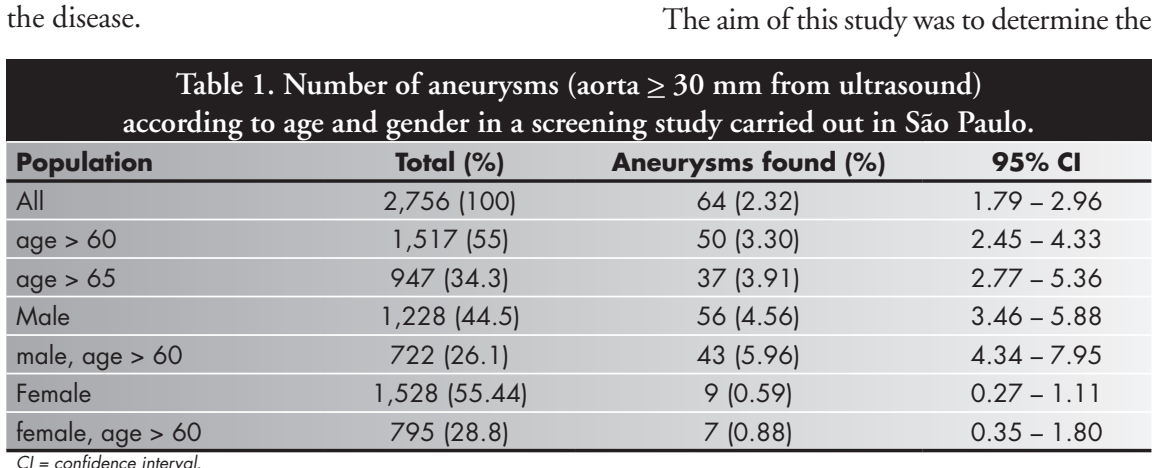

The prevalence of abdominal aortic aneurysms in the population of southeastern Brazil, as estimated from this sample population, is similar or slightly larger than that of other series (Table 4) ${ }^{1-13}$ except for that of Bonamigo and Siqueira, ${ }^{13}$ the only other survey in the Brazilian population. We could not find a reasonable explanation for this discrepancy.

The aim of this study was to determine the

\begin{tabular}{|c|c|c|c|c|c|}
\hline Author & Country & $\begin{array}{l}\text { Population } \\
\text { Gender/age }\end{array}$ & Number screened & $\begin{array}{l}\text { Criteria for positiveness } \\
\text { (diameter in } \mathrm{mm} \text { ) }\end{array}$ & $\begin{array}{l}\% \text { of patients } \\
\text { with aneurysm }\end{array}$ \\
\hline Holdsworth et al. ${ }^{1}$ & United Kingdom & Men/65-79 & 628 & $>29$ & 6.7 \\
\hline Kyriakides et al. ${ }^{2}$ & United Kingdom & Men/65 & 3,497 & $>30$ & 4.9 \\
\hline Vazquez et al. ${ }^{3}$ & Belgium & Men/65 and 75 & 727 & $>29$ & 4.5 \\
\hline Boll et al. ${ }^{4}$ & Netherlands & Men/65-80 & 2,416 & $>29$ & 8.1 \\
\hline Scott et al. ${ }^{5}$ & United Kingdom & $\begin{array}{c}\text { Men/65-80 } \\
\text { Women/65-80 }\end{array}$ & $\begin{array}{l}1,947 \\
2,290\end{array}$ & $\begin{array}{l}>29 \\
>29\end{array}$ & $\begin{array}{l}7.6 \\
1.3\end{array}$ \\
\hline Lindholt et al. ${ }^{6}$ & Denmark & Men/65-73 & 3,748 & $>29$ & 4.1 \\
\hline Krohn et al. ${ }^{7}$ & Norway & Men/> 60 & 500 & $\begin{array}{l}>29 \text { or } 50 \% \text { greater } \\
\text { than proximal aorta }\end{array}$ & 8.2 \\
\hline Collin et al. ${ }^{8}$ & United Kingdom & Men/65-74 & 426 & $\begin{array}{l}>40 \text { or } 5 \mathrm{~mm} \text { greater } \\
\text { than suprarenal aorta }\end{array}$ & 5.4 \\
\hline Lederle et al. ${ }^{9}$ & United States of America & Men/50-79 & 52,745 & $>29$ & 3.6 \\
\hline Lucarotti et al. ${ }^{10}$ & United Kingdom & Men/65 & 4,232 & $\begin{array}{l}26-39 \\
>39\end{array}$ & $\begin{array}{l}7.1 \\
1.3\end{array}$ \\
\hline Ögren et al. ${ }^{11}$ & Sweden & Men/74 & 343 & $>35$ & 11.1 \\
\hline Morris et al. ${ }^{12}$ & United Kingdom & Men/> 50 & 3,030 & $>25$ & 11.1 \\
\hline $\begin{array}{l}\text { Bonamigo and } \\
\text { Siqueira }^{13}\end{array}$ & Brazil & Men/> 54 & 1,012 & $\begin{array}{l}>29 \text { or } 3.5 \mathrm{~mm} \text { greater } \\
\text { than suprarenal aorta }\end{array}$ & 1.7 \\
\hline Present study & Brazil & $\begin{array}{c}\text { Men/> } 50 \\
\text { Women } />50\end{array}$ & $\begin{array}{l}1,228 \\
1,528\end{array}$ & $\begin{array}{l}>29 \\
>29\end{array}$ & $\begin{array}{l}4.6 \\
0.6\end{array}$ \\
\hline
\end{tabular}

Table 2. Number of large aneurysms according to age and gender (aorta $\geq 50 \mathrm{~mm}$ at ultrasound) in a screening study carried out in São Paulo

\begin{tabular}{|c|c|c|c|}
\hline Population & $\begin{array}{l}\text { Total } \\
(\%)\end{array}$ & $\begin{array}{l}\text { Aneurysms found } \\
\text { (\%) }\end{array}$ & $\begin{array}{c}95 \% \mathrm{Cl} \\
(\%)\end{array}$ \\
\hline All & $2,756(100)$ & $9(0.33)$ & $0.15-0.62$ \\
\hline age $>60$ & $1,517(55)$ & $8(0.53)$ & $0.23-1.04$ \\
\hline age $>65$ & 947 (34.3) & $7(0.74)$ & $0.30-1.50$ \\
\hline Male & $1,228(44.5)$ & $7(0.57)$ & $0.23-1.17$ \\
\hline male, age $>60$ & $722(26.1)$ & $6(0.83)$ & $0.31-1.80$ \\
\hline Female & $1,528(55.44)$ & $2(0.13)$ & $0.02-0.40$ \\
\hline female, age $>60$ & $795(28.8)$ & $2(0.25)$ & $0.03-0.91$ \\
\hline
\end{tabular}


prevalence of the disease in the Brazilian population, since there was a lack of data to guide public health policies. The need for future nationwide screening programs has to be analyzed on the basis of efficiency, efficacy and cost.

Much has been written against screening for aortic aneurysms. The points emphasized are: most aneurysms do not require surgical intervention; aneurysms prevail in an age group close to average life expectancy, thus many patients will die from other causes; and detection of a small aneurysm does not indicate a life threatening situation, but such detection may cause psychological stress.
The need for population screening, however, is reinforced by the fact that aortic aneurysms are asymptomatic, potentially lethal and frequently missed at routine medical examinations. Karkos et al., in analyzing the charts from 198 patients who presented with this diagnosis, reported that only $48 \%$ had been discovered clinically, while $37 \%$ were found at radiological examinations for other diseases and $14 \%$ during laparotomy for other procedures. ${ }^{14}$

The decision to screen the whole population of a given country for abdominal aortic aneurysms should be made on the basis of cost-effectiveness. When the cost is covered by governments, priorities have to be decided on the basis of the total budget and the need for screening of other diseases. On an individual basis, however, we must state that each person has the right to know what kind of disease may possibly affect him, and to decide whether to be screened or not, at his own expense.

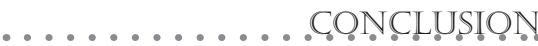

The prevalence of abdominal aortic aneurysm in the population of São Paulo aged over 50 years is between 1.9 and $2.96 \%$. In males who are older than 60 years it is estimated to be 4.34 to $7.95 \%$.

\footnotetext{
1. Holdsworth JD. Screening for abdominal aortic aneurysm in Northumberland. Br J Surg. 1994;81(5):710-2.

2. Kyriakides C, Byrne J, Green S, Hulton NR. Screening of abdominal aortic aneurysm: a pragmatic approach. Ann R Coll Surg Engl. 2000;82(1):59-63

3. Vazquez C, Sakalihasan N, D'Harcour JB, Limet R. Routine ultrasound screening for abdominal aortic aneurysm among 65- and 75-year-old men in a city of 200,000 inhabitants. Ann Vasc Surg. 1998;12(6):544-9.

4. Boll AP, Verbeek AL, van de Lisdonk EH, van der Vliet JA. High prevalence of abdominal aortic aneurysm in a primary care screening programme. Br J Surg. 1998;85(8):1090-4.

5. Scott RA, Ashton HA, Kay DN. Abdominal aortic aneurysm in 4237 screened patients: prevalence, development and management over 6 years. Br J Surg. 1991;78(9):1122-5.
}

6. Lindholt JS, Fasting H, Henneberg EW, Juul S. Forelobige resultater af screening for abdominalt aortaaneurisme i Viborg Amt. [Preliminary results of screening for abdominal aortic aneurysm in the county of Viborg]. Ugeskr Laeger. 1997;159(13):1920-3.

7. Krohn CD, Kullmann G, Kvernebo K, Rosén L, Kroese A. Ultrasonographic screening for abdominal aortic aneurysm. Eur J Surg. 1992;158(10):527-30.

8. Collin J, Araujo L, Walton J, Lindsell D. Oxford screening programme for abdominal aortic aneurysm in men aged 65 to 74 years. Lancet. 1988;2(8611):613-5.

9. Lederle FA, Johnson GR, Wilson SE, et al. The aneurysm detection and management study screening program: validation cohort and final results. Aneurysm Detection and Management Veterans Affairs Cooperative Study Investigators. Arch Intern Med. 2000;160(10):1425-30

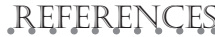

10. Lucarotti M, Shaw E, Poskitt K, Heather B. The Gloucestershire Aneurysm Screening Programme: the first 2 years' experience. Eur J Vasc Surg. 1993;7(4):397-401.

11. Ogren $\mathrm{M}$, Bengtsson $\mathrm{H}$, Bergqvist $\mathrm{D}$, Ekberg $\mathrm{O}$, Hedblad B, Janzon L. Prognosis in elderly men with screening-detected abdominal aortic aneurysm. Eur J Vasc Endovasc Surg. 1996;11(1):42-7.

12. Morris GE, Hubbard CS, Quick CR. An abdominal aortic aneurysm screening programme for all males over the age of 50 years. Eur J Vasc Surg. 1994;8(2):156-60.

13. Bonamigo TP, Siqueira I. Screening for abdominal aortic aneurysms. Rev Hosp Clin Fac Med São Paulo. 2003;58(2):63-8.

14. Karkos CD, Mukhopadhyay U, Papakostas I, Ghosh J, Thomson GJ, Hughes R. Abdominal aortic aneurysm: the role of clinical examination and opportunistic detection. Eur J Vasc Endovasc Surg. 2000;19(3):299-303.

\section{. . P. PU.B.}

Acknowledgements: To General Electric Medical Systems, Boston Scientific Inc. and Banco Bradesco, for their support for the logistic aspects of this study.

Pedro Puech-Leão, MD, PhD. Professor of Vascula Surgery, Department of Surgery, Faculdade de Medicina da Universidade de São Paulo, São Paulo, Brazil.

Lazlo Josef Molnar, MD. Attending doctor, Institute of Radiology, Hospital das Clínicas da Faculdade de Medicina da Universidade de São Paulo, São Paulo, Brazil.

Ilka Regina de Oliveira, MD. Attending doctor, Institute of Radiology, Hospital das Clínicas da Faculdade de Medicina da Universidade de São Paulo, São Paulo, Brazil.

Giovanni Guido Cerri, MD, PhD. Professor, Department of Radiology, Faculdade de Medicina da Universidade de São Paulo, São Paulo, Brazil.

Sources of funding: General Electric Medical Systems, Boston Scientific Inc., Banco Bradesco.

Conflict of interest: None

Date of first submission: August 8, 2003

Last received: October 21, 2003

Accepted: February 2, 2004

\section{Address for correspondence}

Pedro Puech-Leão

Serviço de Cirurgia Vascular

Instituto Central - Hospital das Clínicas FMUSP

Av. Dr. Enéas de Carvalho Aguiar, 255

São Paulo (SP) - Brasil - CEP 05403-900

E-mail: cirurgia.vascular@hcnet.usp.br

COPYRIGHT @ 2004, Associação Paulista de Medicina
Prevalência de aneurismas da aorta abdominal - um programa de detecção em São Paulo

CONTEXTO: O aneurisma da aorta abdominal é uma doença assintomática, mas potencialmente fatal. Correção cirúrgica eletiva pode prevenir a rotura, e está indicada para aneurismas maiores do que $49 \mathrm{~mm}$. Uma vez que os aneurismas tendem a crescer ao longo do tempo, a detecção daqueles pequenos implica em um acompanhamento cuidadoso destes pacientes.

OBJETIVO: Conhecer a prevalência do aneurisma da aorta abdominal na população de São Paulo, Brasil.

DESENHO: Estudo prospectivo, descritivo.

LOCAL: Hospital Universitário da Universidade de São Paulo.

PARTICIPANTES: Foi oferecida, por meio da imprensa, a indivíduos com 50 anos ou mais, a oportunidade de serem examinados para detecção de aneurisma da aorta abdominal. O número total de pessoas examinadas foi 2.756

PROCEDIMENTO: Todos foram submetidos a palpação abdominal e a ultra-sonografia.

VARIÁVEIS ESTUDADAS: Um diâmetro máximo de $30 \mathrm{~mm}$ ou mais foi considerado aneurisma.

RESULTADOS: 64 aneurismas foram detectados, 9 dos quais medindo mais de $49 \mathrm{~mm}$. A palpaçâo detectou 60 aneurismas, mas apenas 20 destes foram confirmados pela ultra-sonografia; por outro lado, 41 dos aneurismas detectados pela ultra-sonografia não eram palpáveis. A percentagem de aneurismas da aorta abdominal encontrados na ultra-sonografia nos subgrupos e o intervalo de confiança de $95 \%$ foram os seguintes: total, 2,3 (1,8-3); homens, 4,6 (3,55,9); mulheres, 0,6 (0,3-1,1); homens com 60 anos ou mais, 6 (4,3-8); mulheres com 60 anos ou mais, $0,9(0,4-1,8)$.

CONCLUSÃO: Em São Paulo, Brasil, estima-se que 1,8 a $3 \%$ das pessoas com 50 anos ou mais tenham aneurisma da aorta abdominal. No subgrupo de homens com 60 anos ou mais, a prevalência está entre 4,3 e 8\%.

PALAVRAS-CHAVE: Aneurisma aórtico. Detecção. Prevalência. Aneurisma. Peneiramento. 